\title{
Nas fábricas, a volta dos velhos tempos
}

Maria Helena Moreira Alves* Roque Aparecido da Silva* *

\section{A} democracia no Brasil nunca ultrapassou os portóes das fábricas. Os trabalhadores vivem o arbítrio total do patronato em seus locais de trabalho. Frequientemente as condiçð̃es de trabalho são intoleráveis, com os trabalhadores sendo forçados a fazer horas extras, chegando a trabalhar mais de 53 horas semanais. O ritmo da linha de montagem é acelerado de acordo com as conveniências da produção e os trabalhadores são então forçados a trabalhar com tal rapidez que não têm tempo nem de satisfazer suas necessidades fisiológicas. A rapidez forçada e a estafa decorrente causam freqüentes acidentes. Nestas condiçøes, o Brasil vem sendo há vários anos o campeão mundial de acidentes de trabalho. Estudos detalhados indicam que em 1980, somente em São Paulo, um em cada seis

\footnotetext{
- Maria Helena Moreira Alves é cientista política, professora no Amherst College, Estados Unidos, $e$ da UERJ, pesquisadora do CEDEC.

* "Roque Aparecido da Silvaé sociólogo, diretor do CEDEC, organizador do livro Os Sindicatos e a Transição Democrática: O Que Pensam os Interessados.
}

trabalhadores sofreram acidentes de trabalho. Esta proporção sobe de um para cada quatro trabalhadores nas indústrias de São Paulo.

Essas condições de trabalho podem ser melhoradas através de negociações diretas, nos próprios locais de trabalho, entre patroes e empregados. A organização dos trabalhadores, através de comissões de fábrica legitimamente eleitas, que viabilizam esse nível de entendimento entre trabalhadores e patroes, é assegurado em todos os países democráticos da Europa, como também nos Estados Unidos, no Canadá e no Japão. Na Alemanha, a representação democrática nos locais de trabalho é um direito dos trabalhadores garantido pela Constituição desde o começo do século. No Brasil, no entanto, os trabalhadores nunca tiveram o direito legal de se organizar de maneira democrática e legítima dentro das fábricas. A legislação trabalhista não permite aos trabalhadores brasileiros uma organização sindical nas empresas. Apesar das dificuldades legais, a partir da retomada de seus movimentos, em 1978 começaram a se organizar dentro das fábricas. Hoje em dia existem comissões de fábrica, eleitas pelo voto direito e secreto dos trabalhadores, em muitas 
das maiores empresas e até de pequenas e médias. São reconhecidas em acordos coletivos que têm um poder de lei, com mandatos estabelecidos, estatutos firmados e estabilidade de emprego reconhecida por contratos registrados em tribunais do trabalho.

Trata-se de uma conquista de fundamental importância para a consolidação da democracia no Brasil. Pela primeira vez os trabalhadores brasileiros começam a abrir caminho para melhorar suas condições de trabalho. As comissðes de fábrica podem negociar, diretamente com os patrōes, sensíveis melhorias nas condiçðes de trabalho e influenciar medidas importantes para diminuir o ritmo das linhas de montagem, reduzir as horas de trabalho e prevenir acidentes.

A Comissão de Fábrica dos Trabalhadores da Ford, criada em 2 de julho de 1981, tornou-se um símbolo dessa conquista. Sua representatividade e legitimidade perante os trabalhadores da Ford foi reconfirmada com a eleição dos membros da Comissão de Fábrica para um segundo mandato com $94 \%$ dos votos. Assembléias internas eram freqüentemente realizadas, em cada setor, para se discutir e propor soluçð̃es para os mais diversos problemas.

A direção da Ford, durante um primeiro período, negociou e dialogou com a Comissão de Fábrica respeitosamente. As melhorias foram sendo conseguidas e a organização democrática dos trabalhadores foi sendo ampliada. Recentemente, porém, houve sensível mudança de tática por parte da direção da Ford, que passou a bloquear de todas as manei- ras o trabalho dos membros da Comissão de Fábrica. A tensão entre trabalhadores e gerência, por isto mesmo, aumentou, até que no dia 14 de julho de 1986 um incidente deslanchou a crise que perturbou gravemente as relaçðes trabalhistas dentro da Ford. Neste dia membros da Comissão de Fábrica foram ao portão da Ford para convencer trabalhadores a não fazer horas extras. Houve um incidente no portão e a Ford alegou que um dos membros da Comissão estava envolvido. Este foi suspenso por trinta dias, apesar de estar em pleno exercício de seu mandato com estabilidade garantida. Depois deste período de afastamento, quando os trabalhadores esperavam poder negociar, a Ford mais uma vez endureceu sua posição e entrou com um processo para o afastamento e demissão do funcionário membro da Comissão de Fábrica. A indignação levou os trabalhadores de sua seção a parar o trabalho temporariamente em protesto. No dia seguinte, 15 de julho, todos os trabalhadores da Ford aderiram à greve de protesto. É importante enfatizar que esta greve, que durou dez dias, teve como objetivo principal a defesa do princípio de organização democrática dentro da fábrica. Os trabalhadores estavam em greve para defender seu direito e pediam a reintegração do funcionário, membro da Comissão de Fábrica, afastado por gesto que julgavam arbitrário.

Esta greve foi reprimida com violência. Presenciamos, pessoalmente, com tristeza, a volta dos velhos tempos. A Ford cercada por um batalhão de choque da PM e os trabalhadores sendo forçados a entrarem na 
fábrica por um "corredor polonês" de policiais militares. Os membros da Comissão de Fábrica e os diretores do sindicato foram impedidos de dialogar. Assembléias para discutir as suas reivindicaçōes foram proibidas e dispersadas, as ruas vizinhas à fábrica fechadas com barricadas e todo o trânsito de acesso desviado. Para evitar maiores problemas, os trabalhadores decidiram terminar a greve e voltar para dentro da fábrica para tentar, novamente, negociar com a empresa. Não houve negociação. No dia 22 de julho uma breve nota formal da Ford comunicava ao Sindicato dos Metalúrgicos de São Bernardo do Campo e Diadema que 24 dos 28 membros eleitos e em exercício de mandato da Comissão de Fábrica estavam afastados (os quatro não afastados estavam de férias). A Ford, depois de trinta dias, entrou com um processo nos termos do artigo 853 da CLT, para afastamento permanente dos membros da Comissão de Fábrica. Além disso, a empresa demitiu um total de 204 trabalhadores, quase todos ativistas, e inclusive seis membros das Comissões Internas de Prevenção de Acidentes (CIPAs), que, pela próprialegislação trabalhista, têm estabilidade garantida. A Ford só aceitou pagar os direitos de 51 deles. Os outros foram, portanto, demitidos por justa causa, sem direito algum. Os trabalhadores continuam querendo ne- gociar, mas estão enfrentando sérios problemas. Sem a Comissão de Fábrica, ficaram sem representação legítima. Apesar de ter demitido tantos funcionários, ainda assim a Ford conseguiu aumentar sua produção em vinte carros por dia. Para isso aumentou a velocidade da linha de montagem, com sérios riscos para a saúde dos trabalhadores que ainda permanecem no emprego.

A Nova República, nestes tempos de transição, não pode se omitir na garantia dos direitos de organização livre dos trabalhadores dentro das fábricas. $\mathrm{O}$ ato da gerência da Ford não deve ser considerado como uma ação restrita somente à própria empresa. Cabe assinalar que a destruição da organização democrática dos trabalhadores dentro das fábricas equivale a um enorme retrocesso, no processo de democratização da sociedade e das relaçðes de trabalho em particular. A Ford daria um enorme exemplo de democracia se tivesse a coragem de reconhecer um erro nas suas relações trabalhistas e aceitasse a reinstalação da Comissão de Fábrica legitimamente eleita e apoiada pelo voto de $94 \%$ dos trabalhadores. A defesa do princípio da liberdade e de organização dos trabalhadores nos locais de trabalho deve ser um ponto central para todos os setores que buscam a consolidação da democracia em nosso país. 